\title{
MIGRACJE MIĘDZYNARODOWE W XXI WIEKU. NOWE TRENDY I WYZWANIA
}

\author{
Agnieszka Piekutowska \\ Uniwersytet w Białymstoku, Wydział Ekonomii i Zarządzania, \\ Zakład Międzynarodowych Stosunków Gospodarczych \\ e-mail: piekutowska@uwb.edu.pl \\ Elżbieta Kużelewska \\ Uniwersytet w Białymstoku, Wydział Prawa \\ Katedra Politologii \\ e-mail: e.kuzelewska@uwb.edu.pl
}

\begin{abstract}
Streszczenie. W artykule omówiono zjawisko migracji międzynarodowych z uwzględnieniem skali, dynamiki oraz barier. Obecnie dynamika migracji międzynarodowych przewyższa dynamikę wzrostu liczby ludności świata, niemniej udział ten wciąż pozostaje na niskim poziomie, bowiem w 2015 r. osiągnął nieco powyżej 3\% populacji świata. W artykule przedstawiono główne przyczyny migracji międzynarodowych, ukazano państwa docelowe i państwa wysyłające. Głównym kierunkiem migracji pozostają państwa rozwinięte z niekwestionowaną pozycją lidera Stanów Zjednoczonych. Niewielka skala migracji międzynarodowych z regionów ubogich wynika z niskiego poziomu dochodów mieszkańców.
\end{abstract}

Słowa kluczowe: migracje, migracje międzynarodowe, neoklasyczna teoria migracji.

\section{WPROWADZENIE}

Według szacunków Organizacji Narodów Zjednoczonych (ONZ) w 2015 r. liczba migrantów międzynarodowych wyniosła 243,7 miliona osób. ${ }^{1}$ Teza przyjęta w niniejszym artykule zakłada, iż po pierwsze, skala migracji międzynarodowych jest ograniczona, natomiast istnieją przesłanki wskazujące na znaczne zwiększe-

1 United Nations, Trends in International Migrant Stock: The 2015 Revision, URL: http:// www.un.org/en/development/desa/population/migration/data/estimates2/estimates15.shtml, [dostęp, 26.05.2017]. 
nie migracji międzynarodowych w przyszłości. Po drugie, skala migracji międzynarodowych pozostaje wyraźnie zróżnicowana w różnych regionach świata. Ujęcie globalne zjawiska migracji pozwoli ukazać znaczenie głównych państw wysyłających i przyjmujących migrantów.

Celem artykułu jest ukazanie skali, dynamiki i zróżnicowania migracji międzynarodowych w XXI wieku. Realizacja celu wymaga wykorzystania metody statystycznej, analizy literatury (w szczególności odnoszącej się do teorii migracji) oraz metody porównawczej. Ze względu na zapewnienie porównywalności danych dotyczących przemieszczeń osób pomiędzy krajami skorzystano z bazy ONZ oraz danych UNHCR.

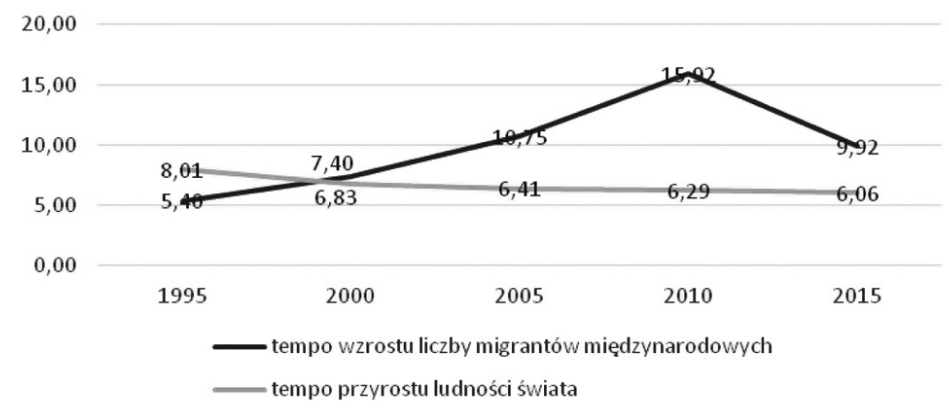

Wykres 1 . Tempo wzrostu liczby migrantów międzynarodowych a tempo przyrostu ludności świata w latach 1995-2015

Źródło: Obliczenia własne na podstawie: United Nations, Trends in International Migrant Stock: The 2015 Revision, URL: http://www.un.org/en/development/desa/population/migration/data/estimates2/estimates15. shtml, [dostęp, 26.05.2017].

Od początku XXI wieku liczba migrantów międzynarodowych nieustannie rośnie, a dynamika tego wzrostu przewyższa tempo wzrostu liczby ludności świata (wykres 1). Powyższe obserwacje zdają się być zgodne z ogólną percepcją nasilenia presji migracyjnej w XXI wieku. Do głównych powodów tego zjawiska należy przede wszystkim kryzys uchodźczy, który dotyczy nie tylko Unii Europejskiej, ale ma znacznie szerszy zasięg geograficzny.

\section{SKALA I DYNAMIKA MIGRACJI MIĘDZYNARODOWYCH. BARIERY MIGRACJI MIĘDZYNARODOWYCH}

W 2000 r. liczba (zasób) migrantów międzynarodowych szacowana była na 172,7 mln osób. Na przestrzeni piętnastu lat liczba ta wzrosła aż o $41 \%$ - do poziomu 243,7 mln w 2015 r. W 2010 r. liczbę migrantów szacowano na $214 \mathrm{mln}$, co oznaczało, że 3,1 \% osób na świecie żyło i pracowało poza krajem urodzenia. ${ }^{2}$ Dy-

2 M. Matkowska, Wspótczesne problemy migracji w Polsce, "Studia i Prace Wydziału Nauk Ekonomicznych i Zarządzania” 2011, nr 4, s. 89. 
namika migracji międzynarodowych przewyższa dynamikę wzrostu liczby ludności świata, efektem czego jest wzrost udziału migrantów w światowej populacji. Należy jednak podkreślić, iż udział ten wciąż pozostaje na niskim poziomie - w 2015 r. osiągnął 3,3\% (wykres 2).

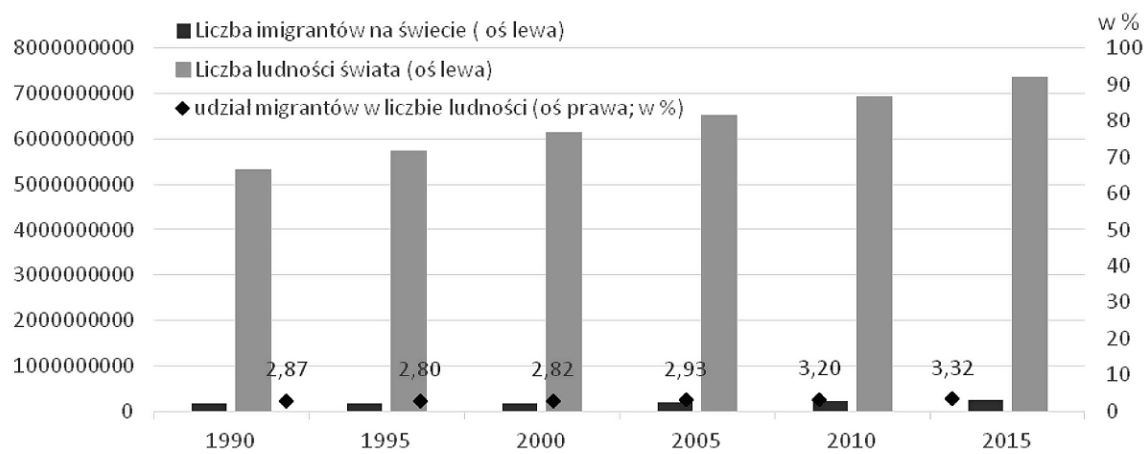

Wykres 2. Udział migrantów międzynarodowych w liczbie ludności świata w latach 1990-2015 Źródło: Obliczenia własne na podstawie: United Nations, Trends in International Migrant Stock: The 2015 Revision, URL: http://www.un.org/en/development/desa/population/migration/data/estimates2/estimates15. shtml, [dostęp 26.05.2017].

Niska skala międzynarodowych migracji w skali względnej (względem populacji świata) na poziomie nieco ponad 3\% wskazuje, że migracje międzynarodowe istotnie ustępują przepływom towarów, a także kapitału. Z tego też względu część autorów argumentuje, że w sytuacji szybkiego tempa wzrostu obrotów handlowych i napływu bezpośrednich inwestycji zagranicznych (w tempie przewyższającym wzrost produkcji światowej), migracje międzynarodowe zdają się być wręcz nieobecne. ${ }^{3}$ Obliczenia wskazujące, że migracje stanowią ok. 3\% populacji świata oznaczają, iż więcej niż 200 milionów osób przebywa dłużej niż rok w innym kraju niż własny, zaś głównym powodem wyjazdu z ojczyzny jest podjęcie pracy. ${ }^{4}$

Ukazanie niskiego udziału migrantów międzynarodowych w populacji świata ma istotne znaczenie. Stanowi podstawę refleksji nad barierami migracji międzynarodowych, choć w ujęciu klasycznej teorii migracji, barier dla migracji nie ma. ${ }^{5}$ W dalszej kolejności pozwoli jednak na prognozę wzrostu migracji międzynarodowych w przyszłości.

3 R. Faini, J. de Melo, K.F. Zimmermann, Trade and migration: and Introduction, in: Migration. The Controversies and the Evidence, eds. R. Faini, J. de Melo, K.F. Zimmermann, Centre for Economic Policy Research, Cambridge University Press, 1999, s. 1.

${ }_{4}$ M. Lesińska, Migracje, http://www.repozytorium.uni.wroc.pl/Content/59052/17_Magdalena_Lesinska.pdf, s. 359-360.

5 W. Janicki, Analiza migracji wewnętrznych i międzynarodowych na obszarze Unii Europejskiej-razem czy osobno?, „Studia Demograficzne” 2006, 2(150), s. 67. 
Badania Adama Smitha, uznawane za początek ekonomicznej analizy migracji, wskazywały na bariery migracji wynikające z natury człowieka. ${ }^{6}$ Argument ten jest jednak niewystarczający dla wyjaśnienia niskiej skali migracji międzynarodowych w ujęciu globalnym. Wyjaśnienie takiego stanu rzeczy wiązać należy przede wszystkim z polityką migracyjną państw docelowych. Jak słusznie wskazuje Böhning, migracja ma miejsce jedynie wówczas, gdy suwerenne państwa (w oparciu o bodźce ekonomiczne) podejmują decyzję o otwarciu granic dla cudzoziemskiej siły roboczej. ${ }^{\text {? }}$

Względnie niska skala migracji międzynarodowych skłania do refleksji w świetle istotnego zróżnicowania rozwoju społeczno-gospodarczego w różnych regionach świata, wyrażającego się m.in. w zróżnicowanym PKB per capita (według parytetu siły roboczej). Podkreślić należy, iż zróżnicowanie dochodu uznawane jest, nie tylko w ramach neoklasycznej teorii migracji, za główny czynnik skłaniający do migracji.

Trafnie dowodził Adam Smith, że migracje wynikają z różnic płacowych. Za punkt wyjścia przyjmował ogromną dysproporcję płac na obszarach wiejskich i miejskich. Ponad 150 lat później w 1932 r. podejście to zostało ugruntowane przez Hicks'a, według którego różnice w korzyściach netto (zwłaszcza różnice w płacach) są główną przyczyną migracji. ${ }^{8}$ Przemieszczanie się ludności uruchamia mechanizm dążący do wyrównania tych wielkości i przywrócenia równowagi na rynkach pracy. ${ }^{9}$ Warto podkreślić, iż oparta o założenie Hicks'a neoklasyczna teoria migracji wywarła ogromny wpływ na postrzeganie migracji i stanowiła podstawy dla kształtowania wielu polityk migracyjnych. ${ }^{10} \mathrm{~W}$ myśl tej teorii osoby ubogie, bez dochodów bądź o niskich dochodach, mogą najwięcej zyskać na emigracji.

Uzupełnieniem wyżej zasygnalizowanych teorii są rozważania Ravensteina nad przyczynami migracji z końca XIX wieku. Jego prace uznaje się za przełomowe, ponieważ przyczyniły się do intensyfikacji badań nad dochodami jako przyczyną mobilności przestrzennej. ${ }^{11}$ Ravenstein wymieniał liczne przyczyny

${ }^{6}$ Smith pisat: ,(...) it appears evidently from experience that a man is of all sorts of luggage the most difficult to be transported"; cyt. za: A. Smith, An Inquiry into the Nature and Causes of the Wealth of Nations, 1776, s. 49-50.

${ }^{7}$ W.R. Böhning, Studies in International Labour Migration, London: Palgrave Macmillan, 1984, s. 33-34.

${ }^{8}$ J. Hicks, The Theory of Wages, Macmillan, London 1932, p. 76 (cytat za: Ö.B. Bodvarsson, N.B Simpson and Ch. Sparber, 'Migration Theory' in: B.R. Chiswick and P.W. Miller (eds.), Handbook of the Economics of International Migration, Vol. 1A, Elsevier 2015.

${ }^{9} \mathrm{M}$. Wosiek, Migracje międzynarodowe w procesach dostosowawczych na rynkach pracy krajów UE w czasach kryzysu, „Prace Naukowe Uniwersytetu Ekonomicznego we Wrocławiu” 2016, nr 449, s. 720.

${ }^{10}$ D.S. Massey, J. Arango, G. Hugo, A. Kouaouci, A. Pellegrino, E. Taylor, 'Theories of International Migration: A Review and Aprraisal' (1993) 19(3) Population and Development Review, s. $433-444$.

${ }^{11}$ M.C. Burda, W. Härdle, M. Müller and A. Werwatz, Semiparametric Analysis of German East-West Migration Intentions: Facts and Theory. Humboldt Universität zu Berlin 1997, s. 2. 
migracji, podkreślając jednocześnie, że migracje spowodowane np. opresjami politycznymi lub niekorzystnym klimatem, są nieporównywalne $\mathrm{w}$ ich zasięgu lub skali do tych, które wynikają z pragnienia nieodłącznego dla większości ludzi poprawy ich sytuacji materialnej. ${ }^{12}$

Wpływ zróżnicowania PKB pomiędzy państwem wysyłającym a państwem docelowym migracji na skalę międzynarodowych migracji zostało potwierdzone w pracach Borjasa. Zdaniem Borjasa wskaźnik emigracji jest negatywną funkcją dochodu w miejscu pochodzenia, negatywną funkcją kosztów emigracji i pozytywnej funkcji dochodów w miejscu przeznaczenia. ${ }^{13}$ Pogląd, zgodnie z którym ludzie migrują dla zmaksymalizowania swej użyteczności, jest obecnie dominujący w teorii migracji międzynarodowych.

Uznając za neoklasyczną teorią migracji, iż głównym czynnikiem sprawczym migracji międzynarodowych jest zróżnicowanie PKB pomiędzy państwem docelowym a państwem przyjmującym, prognozować należy silne przepływy migracyjne w skali światowej w sytuacji tak istotnego zróżnicowania w poziomie rozwoju gospodarczego państw świata. ${ }^{14} \mathrm{~W}$ szczególności spodziewać się można silnych ruchów migracyjnych z państw o najniższym PKB, jako że w świetle przedstawionej teorii obywatele państw najuboższych mogą najwięcej zyskać na migracji. Zgodnie z modelem Borjas'a, emigracja jest negatywną funkcją dochodu w miejscu pochodzenia; zatem im mniejszy dochód w państwie pochodzenia, tym większa presja emigracyjna. Badania empiryczne nie potwierdzają jednak w pełni takiej zależności. Regiony silnie dotknięte problemem ubóstwa nie odczuwają istotnej skali emigracji. Udział emigrantów w populacji państw Afryki Subsaharyjskiej (na poziomie 2,5\%) wyraźnie ustępuje migracjom z państw w mniej dotkniętych problemem ubóstwa regionach świata. Najwyższy udział emigrantów wśród państw rozwijających się odnotowywany jest w regionie Europy i Azji Centralnej (12,2\%), gdzie jednocześnie występuje najniższa stopa ubóstwa. ${ }^{15}$

Niski dochód bądź brak środków może, z jednej strony, stanowić zachętę do migracji, z drugiej natomiast, jej barierę. ${ }^{16}$ Wielu potencjalnych migrantów mających silne pobudki do emigracji określanych w literaturze jako would-be

${ }^{12}$ E.G. Ravenstein, The Laws of Migration, "Journal of the Royal Statistical Society" 1989/52(2), s. 286.

${ }^{13}$ G. J. Borjas, Self-Selection and the Earning of Immigrants, "American Economic Review" 1987/77(4), s. 533.

${ }^{14}$ Przykładowo, PKB per capita według parytetu siły nabywczej Republiki Środkowoafrykańskiej stanowi niespełna $0,5 \%$ PKB Kataru; obliczenia własne na podstawie danych Banku Światowego http://data.worldbank.org [dostęp, 24.05.2017].

${ }^{15}$ KNOMAD - Global Knowledge Partnership on Migration and Development (2016), Migration and Remittances Factbook. Pobrane z: http://www.worldbank.org/en/topic/migrationremittancesdiasporaissues, [dostęp, 24.05.2017].

${ }^{16}$ H.P. van Dalen, G. Groenewold, J.J. Schoorl, Out of Africa: what drives the pressure to emigrate? Journal of Population Economics, Vol. 18, Issue 4/2005, s. 752. 
émigré ${ }^{17}$ pozostaje $\mathrm{w}$ swoim państwie. Ci potencjalni migranci są ,zbyt biedni by migrować". ${ }^{18}$

Wyjaśnienie powyżej opisanej sprzeczności, czyli niskiej emigracji z państw najuboższych, wiązać należy z kosztami migracji. Jak wynika z badań Hattona i Williamsona ${ }^{19}$, pomimo silnych pobudek do emigracji w państwach o niskich dochodach, znaczna część potencjalnych emigrantów nie wyjeżdża, bowiem nie stać ich na pokrycie kosztów migracji (m.in. kosztów podróży czy wydatków związanych z pobytem w państwie docelowym do czasu znalezienia zatrudnienia). Paradoksalnie (w myśl klasycznej teorii migracji) wraz ze wzrostem dochodu w państwach ubogich dochodzi do wzrostu emigracji.

Podejmując próby konceptualizacji nieliniowego związku pomiędzy procesami rozwojowymi a skalą emigracji z danego państwa, Martin i Taylor wprowadzili pojęcie tzw. „garbu migracyjnego” dowodząc, że wraz z rozwojem gospodarczym w danym państwie i zmniejszeniem różnic dochodowych w pierwszym okresie, dochodzi do istotnego wzrostu emigracji, a dopiero w późniejszych fazach spadku emigracji z tego państwa. Takie rozumowanie stanowi uzasadnienie dla opinii i prognoz wskazujących, że w przyszłości (wraz ze wzrostem gospodarczym w krajach najuboższych) może dojść do istotnego zwiększenia skali migracji międzynarodowych.

\section{ZRÓŻNICOWANIE SKALI MIGRACJI MIĘDZYNARODOWYCH W REGIONACH ŚWIATA}

Głównym kierunkiem migracji międzynarodowych pozostają państwa rozwinięte. Udział migrantów w populacji państw rozwiniętych w 2015 r. wyniósł 11,2 \%, podczas gdy udział migrantów w populacji państw rozwijających się jedynie 1,7\%.

Głównym regionem docelowym migracji międzynarodowych (wykres 3) jest obszar Europy, Azji i Ameryki Północnej. W 2015 r. w Europie przebywało 76 mln migrantów, w Azji 75 mln, a w Ameryce Północnej 54,5 mln. W ujęciu dynamicznym wszystkie regiony świata na przestrzeni 15 lat odczuwały stały wzrost liczby migrantów, przy czym najsilniejszy wzrost miał miejsce w regionie Azji. Liczba migrantów wzrosła tam o 52\%.

Zróżnicowanie skali migracji międzynarodowych potwierdza analiza przeprowadzona na poziomie poszczególnych państw (wykres 4).

${ }^{17}$ Bodvarsson Ö.B., Van der Berg H., The Economics of Immigration. Theory and Policy. Springer 2013, s. 432.

${ }^{18}$ T.J. Hatton, J.G. Williamson, Emigration in the long run: evidence from two global centuries, Asian Pacific Economic Literature 23(2)/2009, s. 22.

${ }_{19}$ T.J. Hatton, J.G. Williamson, International Migration 1850 -1939: an economic survey. W: Hatton, T.J., Williamson, J.G. (Eds.), Migration and the International Labor Market 1850-1939, Routledge-London, New York 1994, s. 9. 


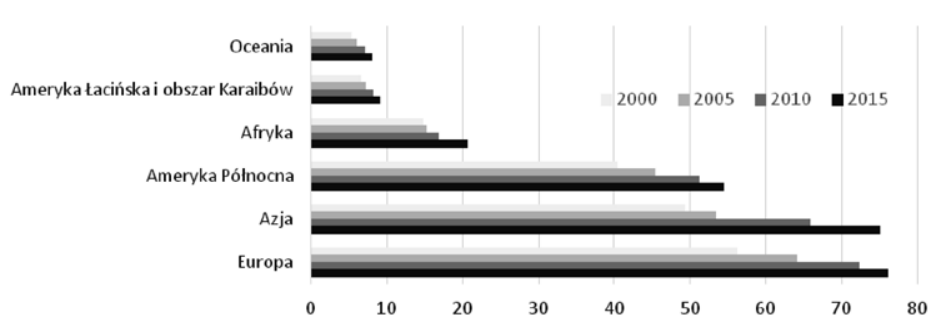

Wykres 3. Migranci międzynarodowi według regionów świata w latach 2000-2015

(w milionach)

Źródło: opracowanie własne na podstawie: United Nations, Trends in International Migrant Stock: The 2015

Revision, URL: http://www.un.org/en/development/desa/population/migration/data/estimates2/ estimates15.shtml, [dostęp 26.05.2017].

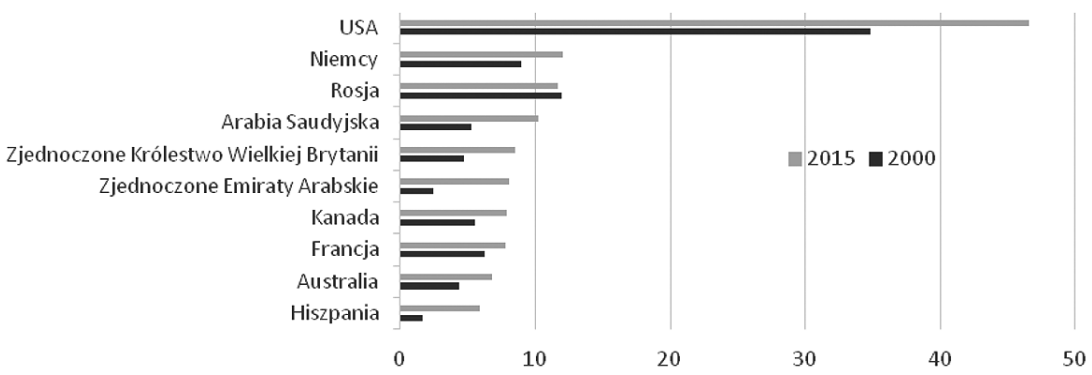

Wykres 4. Liczba migrantów w dziesięciu głównych państwach docelowych (w mln); 2000, $2015 \mathrm{r}$.

Źródło: opracowanie własne na podstawie: United Nations, Trends in International Migrant Stock: The 2015

Revision, URL: http://www.un.org/en/development/desa/population/migration/data/estimates2/ estimates15.shtml, [dostęp, 26.05.2017].

Najbardziej popularnym państwem docelowym dla migrantów pozostają Stany Zjednoczone. W 2015 r. liczba migrantów w USA przekroczyła 46 milionów, co stanowi $14,5 \%$ populacji tego kraju. W państwie tym na przestrzeni ostatnich 15 lat doszło do istotnego wzrostu migrantów o $34 \%$. Interesująca może być rozbieżność definicyjna w literaturze amerykańskiej w odniesieniu do pojęcia migracji ${ }^{20}$ Do znaczącego wzrostu doszło też w pozostałych państwach będących głównymi miejscami docelowymi migracji - z wyjątkiem Rosji. W kraju tym liczba migrantów na przestrzeni 15 lat nieznacznie spadła z 11,9 do 11,6 mln, konsekwencją czego jest przesunięcie Rosji w klasyfikacji głównych państw docelowych z miejsca drugiego na trzecie. Z kolei wzrost migrantów w Niemczech o 34\% na przestrzeni lat 2000 - 2015 skutkuje przesunięciem tego kraju na miejsce drugie w klasyfikacji głównych państw docelowych migracji.

${ }^{20}$ Zob. szerzej: M. Pachocka, J. Misiuna, Migracje międzynarodowe - dylematy definicyjne i poznawcze. Przyklady z Unii Europejskiej i Stanów Zjednoczonych, https://depot.ceon.pl/bitstream/handle/123456789/10273/Migracje_miedzynarodowe_dylematy_definic.pdf?sequence $=1$, s. 304-307; A.E. Jardón Hernández, International Migration and Crisis. Transition Toward a New Migratory Phase, Toluca: Springer 2017, s. 8-9. 
Podkreślić należy, iż dziesięć państw odpowiada łącznie za przyjęcie 51,4\% migrantów międzynarodowych (USA, Niemcy, Rosja, Arabia Saudyjska, Wielka Brytania, Zjednoczone Emiraty Arabskie, Kanada, Francja, Australia i Hiszpania). Występuje więc silna koncentracja napływu migrantów międzynarodowych do wybranych państw docelowych. Niemcy, Francja i Wielka Brytania od dawna stanowiły przykład państw zachodnioeuropejskich o długiej tradycji docelowej imigracji. Wśród migrantów były osoby przemieszczające się w celu poszukiwania pracy, edukacji, łączenia rodzin oraz uciekające przed prześladowaniami politycznymi i religijnymi w swoim kraju. ${ }^{21} \mathrm{Na}$ kształt brytyjskiej polityki migracyjnej wpływ wywierały kolonialne doświadczenia i relacje z państwami należącymi do Wspólnoty Narodów. Migracja do Francji wynikała z posiadania rozległych terytoriów zamorskich oraz przyciągającej gospodarki i kultury francuskiej. ${ }^{22}$ Niemcy z kolei były atrakcyjnym państwem dla migrantów zarobkowych.

Koncentracja migracji międzynarodowych, choć w mniejszej skali, występuje także po stronie państw wysyłających. Za $48 \%$ emigracji odpowiada 20 głównych państw wysyłających (wykres 5). Spośród prawie $244 \mathrm{mln}$ migrantów międzynarodowych, $117 \mathrm{mln}$ pochodzi z dwudziestu państw. W literaturze podkreśla się, iż skrajne ubóstwo jest główną przyczyną migracji. Bez wątpienia brak dochodu czy zbyt niski dochód, uniemożliwiający zaspokojenie potrzeb egzystencjalnych, przyczyniają się do emigracji w celu podniesienia poziomu życia i poprawy sytuacji materialnej. Pogłębiające się zróżnicowanie wynagrodzeń wpływa na zwiększenie presji migracyjnych, zwłaszcza z państw ubogich do państw zamożnych. Teoretycznie w pierwszej kolejności na emigrację decydują się osoby nie mające szans na podjęcie pracy w kraju i zapewnienie rodzinie minimum egzystencji. Przyjęcie takiej tezy może prowadzić do prostego wniosku, że obywatele najuboższych regionów świata - jak Afryka Subsaharyjska - mając najwięcej do zyskania na migracji, będą cechować się największą mobilnością. Tymczasem głównym państwem wysyłającym są Indie. Liczba emigrantów z tego państwa wyniosła 15,6 mln w 2015 r. Warto dodać, że wzrost emigracji z Indii nastąpił wraz z równoległym wzrostem dochodu w tym $\mathrm{kraju}^{23}$, co stanowi przykład potwierdzający występowanie garbu migracyjnego: wraz ze wzrostem dochodu w państwie ubogim, w pierwszym okresie emigracja rośnie, a nie spada.

${ }^{21}$ E. Kużelewska, A. Piekutowska, Doświadczenia i polityki państw Unii Europejskiej wobec uchodźców i imigrantów - perspektywa porównawcza, [w:] K.A. Wojtaszczyk, J. Szymańska (red.), Uchodźcy w Europie. Uwarunkowania, istota, następstwa, Warszawa 2016, s. 287.

${ }^{22}$ H. Wyligała, Problem imigracji w relacjach francusko-niemieckich, [w:] P. Mickiewicz, H. Wyligała (red.), Dokad zmierza Europa: nacjonalizm, separatyzm, migracje - nowe wyzwania Unii Europejskiej, Wrocław 2009, s. 207.

${ }^{23}$ Liczba emigrantów z Indii wynosiła w 1990 r. 6,7 mln, w 2000 r. 7,95 mln a w 2015 r. 15,6 mln. Jednocześnie, PKB per capita (PPP) kształtował się następująco: w $1990 \mathrm{r}-1.146$ USD, w 2000 r. - 1.998,5 USD a w 2015 r. - 6.104,6 USD; Baza Banku Światowego http://data.worldbank. org, [dostęp, 25.05.2017). 


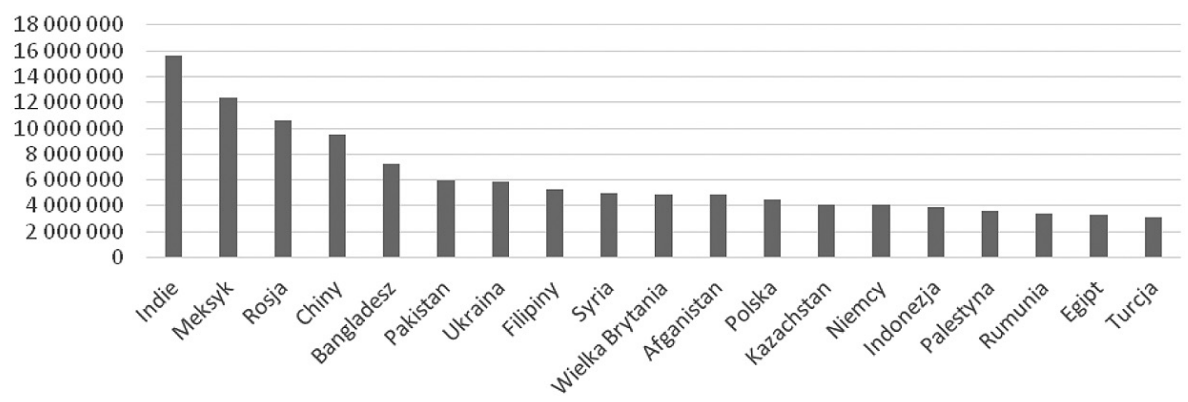

Wykres 5. Liczba emigrantów z dwudziestu głównych państw wysyłających w $2015 \mathrm{r}$. Źródło: opracowanie własne na podstawie: United Nations, Trends in International Migrant Stock: Migrants by Destination and Origin, URL: http://www.un.org/en/development/desa/population/migration/data/ estimates2/estimates15.shtml, [dostęp, 26.05.2017].

Regiony silnie dotknięte problemem ubóstwa nie odczuwają dużej skali emigracji, ponieważ potencjalni emigranci nie wyjeżdżają z uwagi na fakt, iż nie stać ich na pokrycie kosztów migracji. W grupie głównych państw wysyłających znalazły się państwa zróżnicowane pod względem rozwoju gospodarczego, wśród nich trzy państwa o wysokim dochodzie ${ }^{24}$ : Wielka Brytania, Polska, Niemcy oraz pięć państw o średnim - wyższym dochodzie, tj.: Meksyk, Rosja, Chiny, Kazachstan, Rumunia. W grupie dwudziestu głównych państw wysyłających, najliczniejszą grupę (10 państw) stanowiły kraje o niższym - średnim dochodzie: Indie, Bangladesz, Pakistan, Ukraina, Filipiny, Syria, Indonezja, Palestyna, Egipt, Turcja. Zauważyć należy, iż w grupie dwudziestu głównych państw wysyłających tylko Afganistan jest państwem o niskich dochodach, co koresponduje z rozważaniami o ograniczonej emigracji z państw ubogich. Wysoką skalę emigracji z Afganistanu wyjaśnić można nie tylko niskim poziomem dochodu, ale przede wszystkim niestabilną sytuacją polityczną, skłaniającą obywateli do poszukiwania schronienia poza granicami kraju. O ile znaczną część migracji międzynarodowych wyjaśnić można chęcią poprawy sytuacji materialnej migrantów, to istnieje dużo więcej przyczyn migracji, jak np. konflikty zbrojne, skutkiem których jest emigracja przymusowa osób uciekających przed prześladowaniami i opresją oraz ubieganie się o azyl w innych państwach. Głównym powodem migracji w Afryce Zachodniej były wojny domowe w Nigerii, Sierra Leone, Wybrzeżu Kości Słoniowej, Mali i Liberii. W Środkowej i Wschodniej Afryce przez wiele lat toczyły się konflikty zbrojne w Kongo, Rwandzie, Burundi, Ugandzie, Południowym Sudanie i Sudanie. Z kolei Afryka Południowa doświadczyła fali uchodźców w wyniku wojny o niepodległość w Mozambiku i Angoli. ${ }^{25}$

${ }^{24}$ Zgodnie z klasyfikacją państw wg poziomu dochodu Banku Światowego: https://datahelpdesk.worldbank.org/knowledgebase/articles/906519, [dostęp, 25.05.2017].

${ }^{25}$ N. Sander, G.J. Abel, F. Riosmena, The Future of International Migration: Developing Expert-Based Assumptions for Global Population Projections, "Vienna Institute of Demography Working Papers" 2013, nr 7, s. 12. 


\section{KRYZYS UCHODŹCZY GŁÓWNYM WYZWANIEM NIE TYLKO DLA EUROPY}

Spośród 244 milionów migrantów międzynarodowych w 2015 r. 19,6 mln, tj. $8 \%$, stanowili uchodźcy. O ile w wartościach względnych udział uchodźców w grupie migrantów nie wzrósł istotnie, o tyle w wartościach bezwzględnych 2015 r. był niechlubnie rekordowy pod względem liczby uchodźców na świecie (wykres 6).

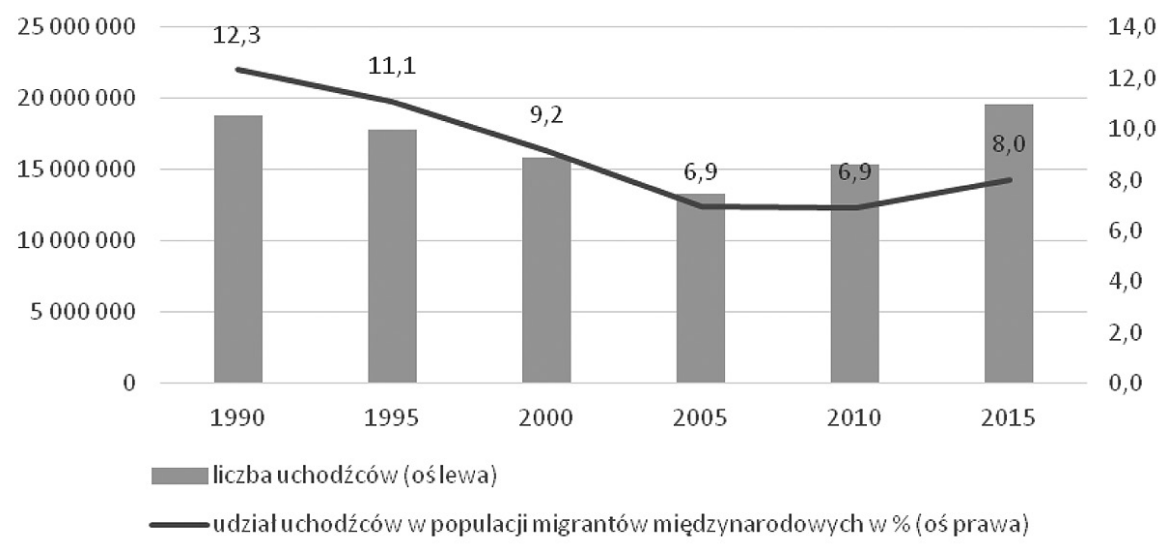

Wykres 6. Liczba uchodźców na świecie oraz udział uchodźców w populacji migrantów międzynarodowych w latach 1990-2015

Źródło: United Nations, Trends in International Migrant Stock: The 2015 Revision, URL: http://www.un.org/ en/development/desa/population/migration/data/estimates2/estimates15.shtml, [dostęp, 26.05.2017].

Powagę sytuacji dodatkowo wzmacnia odsetek osób aplikujących o ochronę. W 2015 r. 3,2 mln osób czekało na decyzję o udzieleniu bądź odmowie udzielenia statusu uchodźcy. ${ }^{26} \mathrm{Nie}$ wszystkim migrantom poszukującym ochrony zostanie ona przyznana. Globalny wskaźnik decyzji pozytywnych w 2015 r. kształtował się na poziomie $57 \% .{ }^{27}$ Jest on zróżnicowany pomiędzy państwami przyjmującymi. Dla przykładu w pierwszej połowie 2016 r. wynosił 99,7\% w Jordanii, $95,2 \%$ w Turcji, 68,3\% w Niemczech, 61,2\% w USA, 12,5 \% na Węgrzech, 6,4\% w Polsce, a $0,7 \%$ w Japonii. ${ }^{28}$

Zjawisko kryzysu uchodźczego w nierównym stopniu dotknęło różne regiony i państwa świata. Przyjmując perspektywę państw wysyłających wskazać należy, że około połowa uchodźców pochodzi z zaledwie trzech państw: Syrii, Afganistanu i Somalii. Liczba uchodźców z tych państw wyniosła w 2015 r. odpowiednio: $4,9 \mathrm{mln}, 2,7 \mathrm{mln}$ i $1,1 \mathrm{mln}^{29}$

Analizując główne regiony i państwa przyjmujące uchodźców, w pierwszej kolejności warto zauważyć, iż 90,02\% uchodźców przebywa w państwach rozwi-

\footnotetext{
${ }^{26}$ UNHCR, Global Trends. Forced displacement in 2015. Geneva 2016, s. 44.

${ }^{27}$ Ibidem, s. 43.

${ }^{28}$ UNHCR, Population Statistics, http://popstats.unhcr.org/en/overview, [dostęp, 26.05.2017].

${ }^{29}$ UNHCR, Global Trends. Forced displacement in 2015. Geneva 2016, s. 3.
} 
jających się, a jedynie $9,98 \%$ w państwach rozwiniętych. O ile więc wysokorozwinięte państwa wyrażają coraz większą troskę o liczbę osób przybywających do granic ich terytorium i ubiegających się o azyl, to głównie państwa rozwijające się udzielają azylu i schronienia uchodźcom na świecie. Fakt, że jedynie jeden na dziesięciu uchodźców znajduje schronienie w państwach wysokorozwiniętych, podkreśla potrzebę większego zaangażowania tych państw w międzynarodową ochronę uchodźców.

Głównymi państwami przyjmującymi uchodźców w 2015 r. były kolejno: Jordania, Autonomia Palestyńska ${ }^{30}$, Liban, Pakistan i Turcja. Państwa te udzieliły w 2015 r. azylu dla 49\% uchodźców na świecie. Tymczasem żadne z państw Unii Europejskiej - wbrew dość powszechnemu przekonaniu - nie znalazło się w grupie dziesięciu głównych państw pobytu uchodźców w 2015 r. ${ }^{31}$ Wbrew powszechnym przekonaniom Grecja i Włochy, apelujące o konieczność współpracy wszystkich państw członkowskich UE w rozwiązaniu problemu migracji ${ }^{32}$, nie należą do ścisłej dziesiątki państw docelowych dla migrantów poszukujących ochrony. Faktem jest, iż dostęp do Europy przez Morze Śródziemne jest najbardziej niebezpieczną drogą pokonywaną przez migrantów, zwłaszcza poszukujących ochrony międzynarodowej. Próby uzyskania dostępu do terytorium zamożnych państw docelowych wiążą się często z podróżą zagrażającą życiu i zdrowiu migrantów. Szacuje się, że w 2016 r. podczas prób dotarcia do państwa docelowego, zginęło na świecie 7872 migrantów, przy czym w drodze do Europy przez Morze Śródziemne zginęło 5098 migrantów. Od początku 2017 r., na Morzu Śródziemnym śmierć poniosło 1530 migrantów. ${ }^{33}$

\section{WNIOSKI}

W świetle zebranego materiału nasuwają się następujące wnioski. Po pierwsze, skala migracji międzynarodowych $\mathrm{w}$ ujęciu bezwzględnym rośnie, a w efekcie tego, że tempo wzrostu liczby migrantów międzynarodowych przewyższa tempo przyrostu ludności świata, udział migrantów międzynarodowych w populacji świata również rośnie. Stale jednak międzynarodowe przepływy siły roboczej pozostają ograniczone i można spodziewać się w przyszłości zwiększenia presji migracyjnej.

Po drugie, występuje zróżnicowanie skali migracji z punktu widzenia regionów i państw docelowych. Głównym kierunkiem migracji pozostają państwa rozwinięte -w 2015 r. 57,6\% migrantów międzynarodowych stanowili migranci w państwach

${ }^{30}$ W 2013 r. przekształcona w Państwo Palestyny.

${ }^{31}$ United Nations, Trends in International Migrant Stock: The 2015 Revision [http://www. un.org/en/development/desa/population/migration/data/estimates2/estimates 15.shtml].

${ }^{32}$ I. Jakimowicz-Ostrowska, Imigracje do Europy wyzwaniem XXI wieku-przypadek Grecji, „Rocznik Bezpieczeństwa Międzynarodowego” 2010/2011, s. 364.

${ }^{33}$ Migrant Fatalities Worldwide, http://missingmigrants.iom.int/latest-global-figures [dostęp, 26.05.2017]. 
rozwiniętych. Co interesujące, w 2015 r. doszło do zmiany pozycji w grupie głównych trzech państw docelowych. Nastąpił spadek migracji do Rosji z równoczesnym wzrostem migracji do Niemiec. Obecnie Rosja zajmuje trzecie, a Niemcy drugie miejsce pod względem liczby migrantów międzynarodowych. Jednocześnie nie doszło do zmiany na pozycji lidera, którym pozostają Stany Zjednoczone.

Po trzecie, analiza migracji międzynarodowych z punktu widzenia państw wysyłających wskazuje na ograniczoną migrację z państw rozwijających się w takich regionach, jak Afryka Subsaharyjska, Azja Wschodnia czy Azja Południowa. Niewielka skala emigracji międzynarodowych z regionów ubogich może być tłumaczona niskim poziomem dochodów. Obywateli państw z tych regionów nie stać na wyjazd, zatem dopiero wzrost gospodarczy (i wzrost dochodów) może doprowadzić do wzrostu emigracji. Oznacza to, iż wraz ze wzrostem gospodarczym w najuboższych częściach świata nastąpić może w przyszłości ożywiona emigracji, z którą zmierzyć się będą musiały państwa docelowe.

W najbliższym czasie najpilniejszym wyzwaniem pozostaje kryzys uchodźczy. Zróżnicowany stopień, w jakim kryzys ten dotknął różne regiony i państwa świata, w tym państwa Unii Europejskiej, utrudnia wypracowanie wspólnych działań wobec problemu uznawanego za jedno z największych wyzwań XXI wieku.

Title: International Migrations in XXI Century. New Trends and Challenges

\begin{abstract}
This article discusses the phenomenon of international migration, including its scale, dynamics and barriers. At present, the dynamics of international migration exceeds the growth rate of the world population, however, this share is still low. In 2015 it reached just over 3\% of global population. The article presents the main reasons for international migration, destination countries and sending countries. The main destination of migration remain the developed states with the undisputed leader of the United States. A small scale of international migration from the poor regions results from low income level of the population.
\end{abstract}

Key words: migrations, international migrations, neoclassical migration theory 